\title{
Influence of Bee Hives Position on Brood Rearing Activity and Stored Pollen in Honey Bee Colonies (Apismellifera L.).
}

Fathy, H. M. ; Laila El- Batran and M. A. A. Ali.

Dept. of Econ.Entomol.; Fac. Of Agric.; Mansoura Univ.; Egypt.

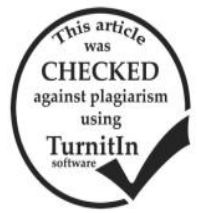

\section{ABSTRACT}

The present work aimed to study the effect of bee hives position (high and low level) on amounts of brood and stored pollen during different seasons. The highest rate of worker brood in upper and lower colonies occurred in May, reached to 627 and 1000 sq.in. /colony, respectively, under (temp. 29 $\mathrm{C}^{\circ}$ and $52 \%$ R.H). Brood rearing in upper colonies was more active than in lower colonies. Throughout different seasons, it was found significant differences between amounts of brood in upper and lower colonies during spring and summer season, while it is not during autumn and winter seasons. Amounts of stored pollen in a whole year in upper colonies were more than lower colonies, represented in upper colonies, 439, 1100, 392 and 158 sq.in. /colony, in spring, summer, autumn and winter, respectively, while in lower colonies were 514, 731, 327 and 164 sq.in./colony, respectively.

\section{INTRODUCTION}

Honeybee colonies have an ability to survive in regions characterize by various environmental conditions. These environmental factors are concentrating upon weather factors and the available food sources. These factors operating simultaneously and it is extremely difficult to measure the effect of one factor apart from the others. So, honeybees react to the environmental conditions in a similar manner wherever they occur. In honeybees, brood plays an important role in the regular development of the colony. For providing the growing larvae brood food (Royal jelly), rich in protein (Crailsheim, 1990).For honeybees' pollen is the most important protein source. The collection of pollen is finely regulated to meet the needs of the colony every subtle ways (Fewell and Winston, 1992). The activities of honeybee colonies are greatly affecting by many environmental factors, such as population size (Chinh et al., 2005), length of worker life (Eishchen et al., 1982). And external conditions such as availability of fresh nectar and pollen (Wille et al,1986). The present work aimed to study the effect of bee hives position (high and low level) on brood activity and amounts of stored pollen.

\section{MATERIALS AND METHODS}

The present study was carried out in a private apiary located at El-Mahalla El Kubra district, Gharbia Governorate, during the period beginning from March 2014 and to February 2015.

For comparison between bee activities in lower hives (located on the floor) and upper hives (located on the fourth floor, 12 meter), ten colonies of honey bee (Apis mellifera L.) $\mathrm{F}_{1}$ Carniolan hybrid were chosen, each headed by a mated queen of similar age .These colonies classified in two groups, the first five colonies were located on the floor and the second five colonies were located on the fourth floor. The bee activities were measured in both groups under temperature and relative humidity condition.

The study was divided in two trends as the following:-

1. Estimation of worker brood rearing activity.

2. Estimation of stored pollen.

1. Estimation of worker brood rearing activity:-

To estimate the rate of sealed worker brood during a whole year, a typical langstroth frame (19 inch in length and seven inch in width) was divided into 133 square inches by means of wire. The frame was laid against any comb to count the number of sealed brood (Fig 1). The count was made at intervals of 12 days according to Al-Tikrity etal. (1971).

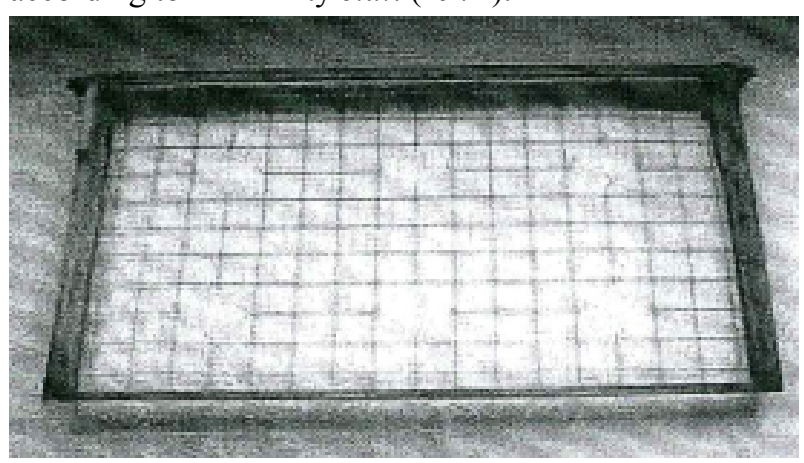

Fig.1. Brood measurement frame

\section{Estimation of stored pollen}

The same previous method of brood estimation was used at 12 days intervals, to count the number of square inches of stored pollen by the worker bees monthly and seasonally. Averages of stored pollen were calculated during the whole year.

3. Determination of temperature and relative humidity.

The averages of temperatures and relative humidity values were recorded. The records were obtained from Sakha of meteorology station, Kafr Elsheikh Governorate. Over a whole year and conducted through the four seasons $(2014 / 2015)$.

\section{Statistical analysis:-}

The data collected were statistically analyzed using general linear models procedure adapted by SAS(2006) for users guide, with a one way ANOVA .Means significance $(\mathrm{P} \leq 0.05)$ using Duncan's multiple range test (1955).Also, correlation coefficients between different factors were used at level 0.05 and 0.01 .

\section{RESULTS AND DISCUSSION}

The present results compared between some bee activities, according to position of hives. (as upper and lower hives). The effect of hives position on brood rearing and stored pollen were studied under temperature and relative humidity conditions.

\section{Worker brood rearing activity.}

Brood rearing is basic a colony development and the maintenance of maximum population during the flow, it is dependent upon the queen capacity to lay eggs, the supporting population ability to maintain favorably temperature and feed the brood reserves of 
pollen and honey, and the proper space for the expansion of the brood nest.

The average of sealed worker brood by each colony was estimated in lower hives (on the floor) and in upper hives (on the fourth floor).

Data presented in Table 1 recorded the monthly and total counts of sealed worker brood (square inches) for the upper and lower hives. Also, results illustrated graphically in (Fig2 )
In general, the data showed that brood rearing level in both colony groups fluctuated slightly from one month to another within the year, but differed greatly between seasons. The results in Table 1 and Fig 2 revealed that the major peak of sealed worker brood occurred during May in lower and upper hives 627and 1000 sq.in., respectively.

Table 1. Monthly and seasonally average of sealed worker brood (sq.in./colony) in upper hives and lower hives under different temperature and relative humidity conditions.

\begin{tabular}{|c|c|c|c|c|c|c|}
\hline Months & Upper hives & n.) & Lower hive & in.) & AV. Temp(C $\left.C^{0}\right)$ & AV.RH\% \\
\hline $\operatorname{March}(2014)$ & 318 & bc & 165 & bcd & 21 & 57 \\
\hline April & 229 & bc & 243 & $b-m$ & 28 & 50 \\
\hline May & 1000 & $\mathrm{a}$ & 627 & $a-m$ & 29 & 52 \\
\hline SPRING & $1547(50.6 \%)$ & & $1035(47.8 \%)$ & & 26 & 53 \\
\hline June & 244 & bc & 129 & cde & 33 & 64 \\
\hline July & 352 & $\mathrm{~b}$ & 178 & bc & 33 & 55 \\
\hline August & 239 & $\mathrm{bc}$ & 251 & b-m & 34 & 54 \\
\hline SUMMER & $835(27.3 \%)$ & & $558(25.8 \%)$ & & 33 & 58 \\
\hline September & 269 & bc & 245 & $b-m$ & 33 & 51 \\
\hline October & 47 & $\mathrm{c}$ & 36 & $f-m$ & 29 & 53 \\
\hline November & 48 & $\mathrm{c}$ & 56 & ef & 25 & 60 \\
\hline AUTUMN & $364(11.9 \%)$ & & $337(15.6 \%)$ & & 29 & 55 \\
\hline December & 69 & $\mathrm{bc}$ & 46 & ef & 22 & 64 \\
\hline January(2015) & 148 & bc & 79 & def & 19 & 61 \\
\hline February & 96 & bc & 110 & cdef & 19 & 63 \\
\hline WINTER & $313(10.2 \%)$ & & $235(10.8 \%)$ & & 20 & 63 \\
\hline Total & $3059(100 \%)$ & & $2165(100 \%)$ & & - & - \\
\hline L.S.D 0.05 & 47.2 & & 49.3 & & - & - \\
\hline
\end{tabular}

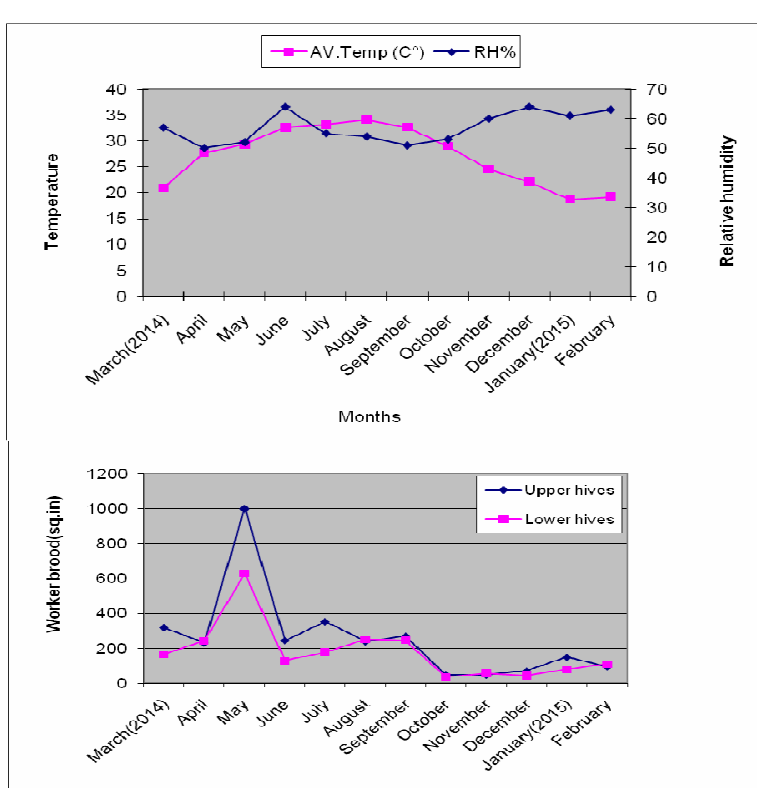

Fig 2. Fluctuation of sealed worker brood(sq.in/colony) in upper hives and lower hives in different months under different temperature and relative humidity conditions.

Analysis of variance in Table (2) showed that there was significant difference between amounts of worker brood during spring and summer seasons in upper and lower hives ., while it was not found significant difference in both hive groups .. Areas of worker brood differed significantly and were high in summer and spring season according to density of bees in upper and lower hives. These fluctuations in brood activities during months of experiment may be attributed to colonies position on floor as lower hives or on the fourth floor as upper hives and beside queen activity, population size and amounts of stored pollen

It could be concluded that upper colonies were more active in brood rearing than lower colonies and this due to abundance of stored pollen in upper colonies (2089 sq.in./colony/year) and decline stored pollen in lower colonies (1736sq.in./colony/year).

It is evident that the queen's fecundity is an important controlling brood, strength of colony and available food of both pollen and honey (Fathy, 1997).

The present study showed that brood rearing activity continues to develop and increase reaching the major peak during May in upper and lower colonies.

The majority of brood rearing activity was observed during spring and summer seasons, while the less activity was observed during autumn and winter seasons. Similar results were obtained by (ELDakhakhni, 1980 and Fathy,1998).

The variation among the two groups (upper and lower colonies) in brood rearing could be mainly attributed to variation in amounts of stored pollen and the population size. (Winston and Fergusson, 1985 and Winston et.al, 1985)

We suggested that that lowest colonies behaving like newly established colonies and upper colonies like well established colonies.

The value of pollen is high to a newly established colony which needs to build up its population to insure over-wintering success and both colony level and individual foraging behavior reflect this increased value. In upper colonies, colony population size changed over time in accordance with increased work effort for pollen 
resources, while the population levels in lowest colonies remained constant.

Table 2. Analysis of variance of sealed worker brood (sq.in./colony) in upper hives and lower hives in different seasons during 2014/2015 at El-Mahalla El-Kubra district.

\begin{tabular}{lcc}
\hline Seasons & Upper hives (sq.in.) & Lower hives (sq.in.) \\
\hline Spring & $1547 \mathrm{a}$ & $1035 \mathrm{a}$ \\
Summer & $835 \mathrm{~b}$ & $558 \mathrm{~b}$ \\
Autumn & $364 \mathrm{~b}$ & $337 \mathrm{c}$ \\
Winter & $313 \mathrm{~b}$ & $235 \mathrm{c}$ \\
F.test & $*$ & $*$ \\
L.S.D $_{0.05}$ & 89.7 & 134.4 \\
\hline
\end{tabular}

\section{Amount of stored pollen}

Data in Table (3) and Fig (3) showed that the average monthly and seasonally count of stored pollen per colony in upper and lower colonies.

A slight decrease in stored pollen was observed during April (39sq.in./colony) in lower colonies, while was in March (48 sq.in./colony) in upper colonies.

The highest rate of gathering pollen observed during May in lower colonies, recorded (432 sq.in./colony) while in upper colonies recorded (519sq.in./colony) in July. Also in June, large amounts of stored pollen were recorded (303 and 251 sq.in./colony) in upper and lowest colonies, respectively.

Table 3. Monthly and seasonally average of stored pollen (sq.in./colony) in upper hives and lower hives under different temperature and relative humidity conditions.

\begin{tabular}{|c|c|c|c|c|}
\hline Months & Upper hives (sq.in.) & Lower hives (sq.in.) & AV.Temp $\left(C^{0}\right)$ & AV.RH\% \\
\hline$\overline{\operatorname{March}(2014)}$ & $48 \mathrm{~cd}$ & $43 \mathrm{~d}$ & 21 & 57 \\
\hline April & $61 \mathrm{~cd}$ & $39 \mathrm{~d}$ & 28 & 50 \\
\hline May & $330 \mathrm{a}$ & $432 \mathrm{a}$ & 29 & 52 \\
\hline SPRING & $439(21 \%)$ & $514(29.6 \%)$ & 26 & 53 \\
\hline June & $303 \mathrm{c}$ & $251 \mathrm{bc}$ & 33 & 64 \\
\hline July & $519 \mathrm{ab}$ & $277 \mathrm{~b}$ & 33 & 55 \\
\hline August & $278 \mathrm{ab}$ & $203 \mathrm{bc}$ & 34 & 54 \\
\hline SUMMER & $1100(52.7 \%)$ & $731(42.1 \%)$ & 33 & 58 \\
\hline September & $225 \mathrm{~b}$ & $187 \mathrm{bc}$ & 33 & 51 \\
\hline October & $73 \mathrm{~cd}$ & $68 \mathrm{~cd}$ & 29 & 53 \\
\hline November & $94 \mathrm{~cd}$ & $72 \mathrm{~cd}$ & 25 & 60 \\
\hline AUTUMN & $392(18.8 \%)$ & $327(18.8 \%)$ & 29 & 55 \\
\hline December & $119 \mathrm{c}$ & $106 \mathrm{~cd}$ & 22 & 64 \\
\hline January(2015) & $18 \mathrm{~cd}$ & $26 \mathrm{~d}$ & 19 & 61 \\
\hline February & $21 \mathrm{~cd}$ & $32 \mathrm{~d}$ & 19 & 63 \\
\hline WINTER & $158(7.5 \%)$ & $164(9.5 \%)$ & 20 & 63 \\
\hline Total & $2089(100 \%)$ & $1736(100 \%)$ & - & - \\
\hline L.S.D ${ }_{0.05}$ & 50.9 & 73.2 & - & - \\
\hline
\end{tabular}

The results obtained declared that the highest rate of stored pollen was observed during spring and summer seasons, represented. (439 sq.in. 21\%) and (1100 sq.in. 52.7\%) in upper colonies, while was (514 sq.in. $29.6 \%$ ) and (731sq.in. $42.1 \%$ ) in lowest colonies, respectively.

These percentages were due to the suitability of ecological condition for plant flowering and the highest population of foraging bees that good gather the pollen from the blooming plants in these periods such as clover,citrus,some ornamental plants and some vegetables.The percentage of collected pollen during autumn season was estimated. (18.8\%) in both two groups (upper and lower colonies)

Most of these pollen grains were collected in September and this agree with the finding of ELDakhakhni (1980). The lowest amount of pollen in winter season was due to the lack in pollen sources and decreased of temperature degree (18.7 c0 in January), which greatly affect foraging activity of bees.

Generally, data presented in Table (3) indicated that amounts of stored pollen in upper colonies were higher for all season than in lower colonies. They were (439 sq.in. $21 \%, 1100$ sq.in. 52.7,392 sq.in. $18.8 \%$ and 158 sq.in.7.5\%) in upper colonies, while in lower colonies were (514 sq.in. $29.6 \%, 731$ sq.in. $42.1 \%, 327$ sq.in. $18.8 \%, 164$ sq.in. 9.5\%) for spring, summer, autumn and winter, respectively.
The yearly amounts of stored pollen (per/colony) in upper and lower colonies were 2089 and 1736 sq.in., respectively.

Taha (2006) reported that the yearly amounts of stored pollen per colony in Carniolan, Italian and F1 Italian were 2338, 1885 and 1690 sq.in., respectively. And El-Dakhakhniet al.(1986) in F1Carniolan was 2847 sq.in., while in our results was 2089 and 1736 sq.in.in upper and lower colonies. This variation in amounts of stored pollen may be due to variation in climatic condition, hives position, pollen source and bee races.

Analysis of variance showed that there is a significant difference between amounts of stored pollen during spring and summer season in upper and lower colonies, while it was insignificant between upper and lower colonies in autumn and winter Table (4).

Areas of stored pollen differed significantly and were high in summer and spring according to population size.

These fluctuations in stored pollen activities during months of experiment year may be attributed to hive position on floor or on fourth floor, availability of pollen sources, colony strength and hereditary behavior suitability of environmental condition. (Fig.3)

It could be concluded that upper colonies were more active in collected pollen than lower colonies. 
Table 4. Analysis of variance of stored pollen (sq.in./colony)in upper hives and lower hives in different seasons during 2014/2015 at ElMahalla El-Kubra district.

\begin{tabular}{lcc}
\hline Seasons & Upper hives (sq.in.) & Lower hives (sq.in.) \\
\hline Spring & $439 \mathrm{~b}$ & $514 \mathrm{~b}$ \\
Summer & $1100 \mathrm{a}$ & $731 \mathrm{a}$ \\
Autumn & $392 \mathrm{c}$ & $327 \mathrm{c}$ \\
Winter & $158 \mathrm{c}$ & $164 \mathrm{c}$ \\
F.test & $*$ & $*$ \\
L.S.D $_{0.05}$ & 123.1 & 68.1 \\
\hline
\end{tabular}
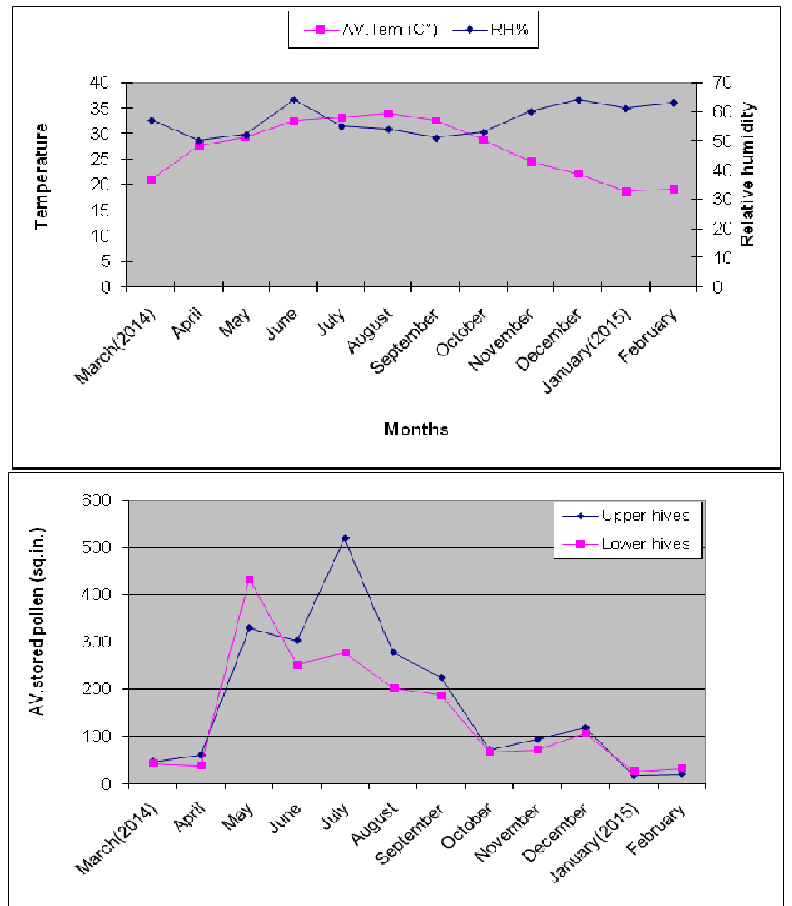

Fig 3. Fluctuation of stored pollen (sq.in./colony) in upper hives and lower hives in different months under different temperature and relative humidity conditions.

\section{REFERENCES}

Al-Tikrity, W.S.;Hillmann. R.C.;Benton, A.W. and Clarke, W.W. (1971). Anew instrument for brood measurement in honey bee colonies. J. of Amer.Bee Journal.111(4):143-145.
Crailsheim, K. and Stotberg, E. (1990). Influence of diets, age and colony Condition upon intestinal proteolytic activity and size of the Hypopharyngeal glands in the honey bee (Apismellifera L.). J. Insect physiol., 35 (8):595-602.

Eishechen, F.A.;Rothenbulier, W.C. and Kulince Vie, J.M.(1982). LengthOf life and dry weight of worker honey bees reared in colonies withdifferent workerlarvae ratios. J. Apic. Res. 21(1): 19-25.

El-Dakhakhni,N. M. (1980).Studies on the honey bee(Apis mellifera L.). Ph.D.Thesis, Fac.Of Agric. Alexandria Unversity.

El-Dakhakhni, N.M.; Zhenishen, Z. and shawer, M.B. (1986). Feeding Honey bee colonies with a pollen substitute and its influence on brood Rearing a honey production. Bull. Soc. Ent. Egypt., 66: 57-64

Fathy, H. M. (1997).Honey bee colony population in relation to brood rearingand stored pollen. Arch. Phytopath. Pflanz; 1997.Vol. 30. pp. 445-452.

Fathy, H. M. (1998). Seasonal variations in brood rearing activity and stored according to colony strength. J. Agric. Sci. Mansoura Univ., 23(12):6231-6237.

Fewell, J.H and Winston ML (1992). Colony state and regulation of pollenForaging in the honey bee, Apismellifera L. BehavEcolSociol 30: 387-394.

SAS Institute. 2006. SAS. User's Guide Statistics. SAS Institute, Cray, NC.

Schmidt, J.O.and Buchmamnn, S.L.(1992). The hive and the honey bee. J.M. Graha ed. Dadant and Sons: Hamilton, IL.1324PP.

Taha, A. A. (2006). Comparative studies on some secondary products in differentraces of honey bees. Ph. D. Thesis, Fac. Mansoura Univ.222pp.

Winston, M. L. and Fergusson, L. A. (1985).The effect of worker loss on Temperora caste structure in colonies of the honey bee (Apismellifera L.). Conf. J. Zool, 63: 777-780.

Winston, M. L.; Mitchell, S.R. and Punnett, E.N. (1985).Feasibility of package honey bee (Hymenoptera, Apidae). Production in Southwestern British Columbia, Canada. J. Econ. Entomol, 78:1037-1043.

\section{تأثير موقع الخلايا على نشاط الحضنة وحبوب اللقاح المخزونة فى طوائف نحل العسل .

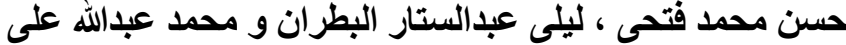 قسم الحشرات الإقتصادية ـ كلية الزراعة ـ جامعة المنصورة}

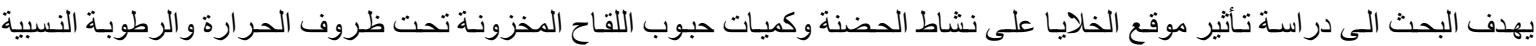

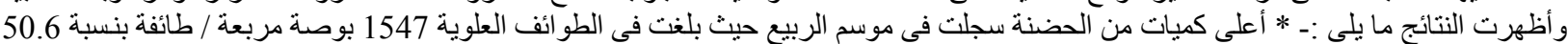

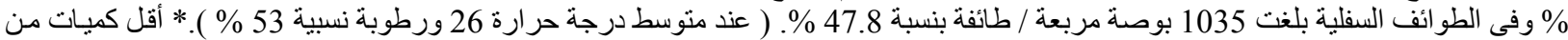

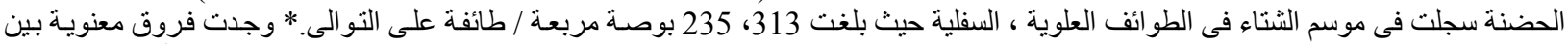

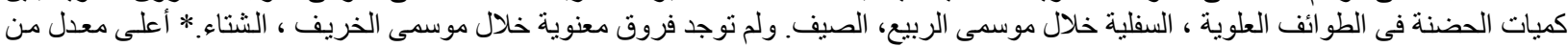

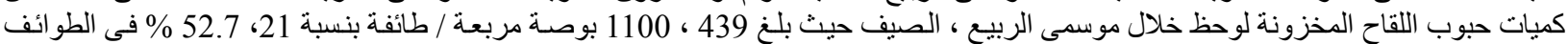

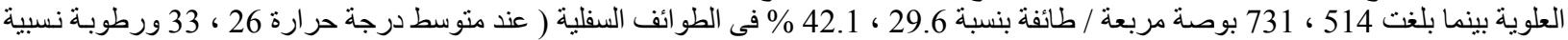

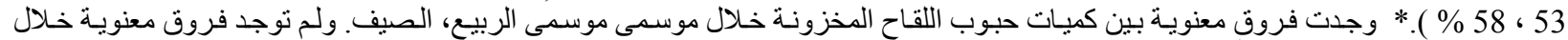
موسمى الخريف ، الثتاء فى كلاً من الطو معنف ائف العلوية ، السفلية. 